ARTICLE

Received 5 Aug 2014 | Accepted 30 Mar 2015 | Published 12 May 2015

DOI: $10.1057 /$ palcomms.2015.9

\title{
"When you see the lipstick kisses ..." - military repatriation, public mourning and the politics of respect
}

Sandra Walklate ${ }^{1}$, Gabe Mythen ${ }^{2}$ and Ross McGarry ${ }^{2}$

\begin{abstract}
Between 2007 and 2011, a small town in Wiltshire became indelibly associated with the repatriation of military personnel killed as a result of British involvement in the conflicts in Iraq and Afghanistan. This article offers some empirical insight into, and analysis of, what this process of bringing the dead back home meant for the people of Wootton Bassett, a town afforded "Royal" status for their role in this particular repatriation process. The data gathered affords a unique opportunity to offer some general reflections on the presence of death and the politics of respect evidenced during this time and the wider implications that these process have for making sense of the ineffable within contemporary society. We suggest that Royal Wootton Bassett has not only changed the way in which we "mark the sacrifice of war", but also encourages us as social scientists to critically reflect on the extent to which the theories that we have enable us to make sense of contemporary practices of public mourning.
\end{abstract}

\footnotetext{
${ }^{1}$ Liverpool University, Liverpool, Merseyside, UK ${ }^{2}$ Department of Sociology, Social Policy and Criminology, University of Liverpool
} 


\section{Introduction}

Every time a fallen war hero is returned to home soil, their Union Flag-draped coffins travel through Wootton Bassett. And every time the townspeople turn out in their hundreds to pay silent tribute to the servicemen and women who have paid the ultimate sacrifice for their country. (Bond, 2008)

$\mathrm{B}$ etween 2007 and 2011, a small town in Wiltshire became indelibly associated with the repatriation of military personnel killed as a result of British involvement in the conflicts in Iraq and Afghanistan. In the words of Mark Sheldon, the father of deceased rifleman Adrian Sheldon: "If Adrian could speak now he'd say, if you die, normally you see Angels and you'd be off to heaven. If you're a soldier, you see Wootton Bassett" (cited in Etchingham, 2011). Such emotionally charged sentiments aside, the events which transpired in Wootton Bassett during this 5-year period were culturally remarkable and have arguably contributed to changing public attitudes towards the commemoration of soldiers killed in Iraq and Afghanistan (see Etchingham, 2011). In this article, we seek to draw on ethnographic fieldwork conducted in Wootton Bassett to illuminate some of the socio-cultural peculiarities of what has been dubbed "the Wootton Bassett effect" (Bagehot, 2011). In particular, we seek to engage in a thematic analysis of two aspects of the events connected to these military repatriations: the politics of respect and managing the presence of death.

So far as the United Kingdom is concerned, the repatriation of soldiers killed during warfare is a relatively recent phenomenon. During the First and Second World Wars, soldiers were traditionally buried close to where they fell (see Winter, 1998). The abundance of Commonwealth war graves in parts of Northern France and Southern Belgium stand as testimony to this policy. However, since the Falklands War of 1982 the families of all serving personnel killed in battle-not just those of senior officers-were afforded the opportunity to bring the bodies of their loved ones home at the expense of the Ministry of Defence. Given the increasingly global nature of military conflicts, this practice has since become the norm as evidenced in the comparative analysis of soldier repatriation offered by Martinsen (2013). The factors underpinning this shift are manifold and include practical considerations such as uncertainty about adequate maintenance of graves abroad and a desire to return the bodies swiftly (see Jenkings et al., 2012). Understanding this wider context of repatriation enables us to glimpse some of the nascent transformations in practices of public commemoration and also shifts in the ways in which our relationships with the dead are socially managed.

Arguably in Britain new patterns of memorialization have emerged over the last two decades, associated with what Kellaher and Worpole (2010) call "bringing the dead back home". They suggest that contemporarily bereaved families search for a place of mourning and commemoration-both for themselves and for the deceased-that "fits" (Kellaher and Worpole, 2010: 178). In an earlier exploration of repatriations at Wootton Bassett, we attempted to explore this search for a place that "fits" through the use of photographic images (Walklate et al., 2011). By deconstructing the images of "mourners" who presented themselves at Wootton Bassett we suggested that there were a number of interconnected ways of making sense of them and the possible reasons for their presence at such events. ${ }^{1}$ As the analysis of Jenkings et al. (2012) implies, the influence of the media on public attendance at such events is an important factor to be taken into consideration. Further, there was doubtless, for a minority in attendance, a vicarious curiosity present more akin to modes of "dark tourism" (Foley and Lennon, 1996, 2010) than the sombre passing of respect. It is also the case that the invasion of Iraq and the subsequent conflict in Afghanistan have been unpopular wars in terms of public support, although curiously this has not translated into a lack of support for the military (see, inter alia, British Social Attitude Survey, 2012). It should be remembered that the proposed invasion of Iraq in 2003 prompted the largest public demonstrations ever seen in the United Kingdom-attended by well over a million peopleindicating disquiet about military strategy and contributing towards ambivalence for this intervention (see McGarry et al., 2012; Martinsen, 2013). British Armed Forces were subsequently deployed in Iraq and Afghanistan for over a decade. At the time of writing (March 2015) British military forces have been withdrawn from both of these wars at the cost of 632 British military lives. ${ }^{2}$

During the years 2007-2011, the bodies of dead personnel killed in Afghanistan and Iraq were repatriated to the United Kingdom by plane, landing at Royal Air Force (RAF) Lyneham. ${ }^{3}$ En route to the Coroner's Office for post-mortem reports at the John Radcliffe Hospital in Oxford, the hearses happened to pass through the town of Wootton Bassett. What prompted local people to begin to pay their respects to the funeral cortege as they passed through the town is locally contested. Nevertheless, the most commonly expressed narrative points to the chance momentary salute of a hearse by a member of the Royal British Legion as one cortege passed by. To this end, it is a moot point concerning the extent to which what transpired was an "invented tradition" (Drake, 2013b: 220) or was indeed framed by any particular ritual of remembrance as approved by the Royal British Legion. What is not in dispute is that this spontaneous action is said locally to have heralded the start of a 4-year period in which tens of thousands of people turned out to pay their respects to fallen servicemen and women. When it became clear that the bodies of soldiers were to be returned via RAF Brize Norton rather than RAF Lyneham-and subsequently no longer be routed through Wootton Bassett-the town was bestowed with the name "Royal Wootton Bassett" by Her Majesty the Queen, in recognition of the social importance of these events. This marks what Drake (2013b: 221) suggests is a moment in which these events became part of a "patriotic heritage" rather than "unplanned and spontaneous". The movement of soldiers' bodies via the process of repatriation continues but the families of the deceased are now able to witness the repatriation at a Commemorative Centre in RAF Brize Norton. Members of the public are permitted to line an exit road situated at the rear entrance of the airbase-far removed from the nearby town of Carterton-which is now on the route to the Coroner's Office. The declining level of media interest and coverage since the handover to Brize Norton and Carterton has been striking, thus adding a further layer of curiosity around the origins, nature and meaning of the events in Royal Wootton Bassett.

In understanding the motivation behind public involvement in these events, there is no doubt that the "impulse to follow the dead", noted by Woodward (2009), increasingly expressed as a social grief-reflects what Valier (2004: 321) has called "the public performance of collective acts of mourning". In this article, we wish to explore this public performance from the perspective of those who were centrally engaged in its production: the local people of Royal Wootton Bassett. Here, we offer a more nuanced and empirically grounded analysis of one of the themes suggested in our earlier work: the compression of private and public grief. This analysis is partly derived from Giddens's (1991) work on sequestration and based on data gathered in conversations with the people of Royal Wootton Bassett themselves. Thus, we consider these events to be suggestive of something more than being "contingent, even potentially cynical, or at least empty of authenticity" (Drake, 2013b: 221). 
We should make our epistemological position clear from the outset. Taking on board Stanley and Wise's (2011: 948) critique of the sequestration thesis, we would concur with their summation that:

A fully articulated theorization of death needs to be grounded, historicized and comparative; to explore such matters through the lens of domestic figuration; and to deal with the ontological and epistemological issues raised by death with which the bereaved necessarily have to deal.

In sympathy with this approach, it is our intention here to focus on ontological and epistemological problematiques around the nature of life and death. We will thus be resisting the temptation to present what happened in Royal Wootton Bassett as simply a further example of a growing tide of conspicuous public mourning that Doss (2008: 7) has dubbed "memorial mania". Rather we will be digging a little deeper into seams of social experience that are more complex, ambiguous and labile than such a categorization permits.

The article falls into three parts. First, we wish to explicate the purpose of our study in Royal Wootton Bassett and elucidate our methodological approach. Second, in concert with the intention signalled above, we offer an account of two salient themes that emerged in the analysis of our data. Third, in considering the presence of death, we wish to deliberate upon the sociological significance of our empirical observations by deploying Berlant's (2011) concept of "intimate publics" as an analytical entry point worthy of further development.

\section{Contextualizing the study: trajectory, design, approach}

Presented as an ethnography at "short" and "long range" (McGarry et al., 2013; McGarry, forthcoming), our interest in Royal Wootton Bassett began some time ago in the classroom at the University of Liverpool. Here, we posed a simple question during a seminar discussion: "What is Wootton Bassett about?" To explore this question we used several photographs taken of a military repatriation at Royal Wootton Bassett by an independent professional photographer (and colleague). ${ }^{5}$ During the seminars we asked students $^{6}$ to document their own ideas of what they thought "Wootton Bassett was about". Some of their responses included:

'Displays of peace and solidarity to bring calm back to the community and country after soldiers have lost their lives in the war. It is a time of reflection'

'Grieving as a nation'

'Respect for British soldiers-a place where people can offer tributes to those that have died'

'Honouring fallen soldiers'

'Collective interests'

In making these statements the students reflected general normative understanding of what the military repatriations comprised as elicited by the photographs we used. They perhaps also illustrated some common-sense understandings of military losses and the conduct of funeral processions: respect, grief, reflection and commemoration. In an attempt to begin shaping a cultural understanding of the military repatriations, we proposed a victimological analysis of these photographs and suggested that they could be understood to represent different frames of meaning: as a public outlet for privatized grief, as evidence of dark tourism (Foley and Lennon, 1996, 2010), or as displays of apolitical resistance against the wars in Afghanistan and Iraq (see Walklate et al., 2011). Since the publication cited previously, other literature has emerged concerned with a conceptual analysis of the dead body of the solider (see, for example, Drake, 2011,2013a, b), with the memorial work achieved by events such as these (Allen, 2015) and indeed the media coverage of them (Jenkings et al., 2012).

Like many people, our initial interest in Wootton Bassett was piqued by media images of the growing numbers of people lining the town's high street. Attendance at a repatriation event was attended, along with extensive analysis of media and political analysis of events in the town, provided the backcloth against which we settled on a study oriented towards three overarching strands of investigation: place, repatriation and soldiering. From October 2012 to February 2013, we made several further research visits to the town, conducted 4 focus groups with local people, ${ }^{7}$ and 12 semi-structured interviews with individuals involved in different ways in the repatriation process, including police officers, military personnel and representatives from the local council, church and college. Following Braun and Clarke (2006), we began our thematic analysis by familiarizing ourselves with the focus group data, generating initial codes and excavating primary themes. These themes were reviewed internally and we then employed an external independent researcher who coded and analysed the data.

Given that the study has involved both distant observations and intensive periods of embedded research in the town, we would classify the study as a stretched ethnography. Inasmuch as we developed the study from long range we have also interrogated our perceptions as outsiders through being in the town and investigating it at short range (see McGarry, forthcoming). Our approach has enabled us to maintain a critical distance while also developing extensive knowledge of the town, ably assisted by many of the people that live there, particularly members of the town council. We have built up knowledge about the social history of Royal Wootton Bassett and the repatriations that occurred there by various means, including analysing media archives and documentary footage, and latterly studying letters, poetry, gifts and other commemorative memorabilia sent by members of the public to the town council. Drawing on the ethnographic tradition, we have sought to engage in "intelligent noticing" in our site observations in the town (see Thomas, 2010: 587) and have endeavoured to produce what Fassin (2014) might call an ethnography geared towards "comprehensive generalization". Thus our thematic analysis needs to be considered against the backdrop of a suite of data that includes photographs, observations, note taking, transcribed interviews and document analysis. In interaction with local people and key stakeholders we have been able to decipher some of the meanings attributed to the repatriation process. Here we consider two interconnected themes that emerged through data analysis: the politics of respect and managing the presence of death. We shall now discuss each of these in turn.

\section{Repatriation: developing a politics of respect}

In the BBC documentary The Town that Remembers, a woman from Royal Wootton Bassett reflects on the passing through of soldiers, stating: "we couldn't let them go without paying respect to them: it wouldn't be right". This assertion puts to the fore a common theme that arose frequently in people's narratives in our study: the paying of respect. In the discussions that we facilitated, the paying of respect was culturally constituted by a number of factors, including inter alia, duty, modesty and justness. These three elements occurred frequently in conversations regarding people's reasons for gathering to line the streets in the town:

Jimmy: I do it because I want to pay respects. If it was in Cambridge, or Leeds or somewhere like that and a hearse went past, I guarantee that a member of the British Legion, if he saw it, would stand to attention and salute. No matter where it 
would be, he would pay his last respects. It just so happens that it comes through Wootton Bassett.

The quote above captures the essence of how, for local people, the events at Royal Wootton Bassett first came to pass. Yet in this statement there is also both a nod to duty and an expressed modesty that was recurrent in our conversations with many people that we spoke to. The prevailing sense we gained was that the people of Royal Wootton Bassett did not do anything out of the ordinary, or anything that required the bestowal of high praise. For members of the local branch of the Royal British Legion these actions are perhaps not unusual and may constitute something of an expectation that ex-military personnel have of themselves and their comrades. As Jimmy went on to say:

Jimmy: People don't seem to realise that in the Forces when you are working together ... comradeship is a very strong bond. You get very close-knit. Not only with your lads around you, but your officers as well. And if you don't pull together you won't survive.

For Jimmy, the paying of respects in this context is conceived as a natural extension of his military experience and the desire to acknowledge the importance of that experience for others. However, as time went on, it became apparent that "paying of respects" was occurring on a much larger collective scale and that the reasons for this were complex and diverse. Not only local people of a non-military background, but also thousands of people from outside the area came to be involved in this process. These "outsiders" were seen, on the whole, to be mindful of the ethos of gatherings and sensitive to the centrality of respect. Yet the nature of the repatriations and, in particular, how they were described was clearly a source of some contention, as were the range of actions considered appropriate. The exchange below in the Royal British Legion focus group is instructive in this regard:

Jimmy: Well, it's not a ceremony. We're standing by the side of the road and as the hearse goes past, we are paying our respects. It is not a ceremony. It started out as just a hearse going through. It wasn't until later, when the crowds started coming, that they stopped to allow them to put flowers on top.

Andrew: They were throwing flowers before, and the police said it was dangerous. Safety of the drivers, it might put them off.

Cathy: It was words that the media used. 'Ceremony' and 'parade' were two of the words that the press used. I suppose for want of better words for how to describe it. To us, it was a gathering. It wasn't a parade, it wasn't a ceremony, it was just a gathering of people to pay respects.

These kinds of reflections and negotiations around the nature and meaning of the repatriations was certainly not unique to members of the Royal British Legion. A worker at the town council offices had this to say:

Barbara: I guess the picture in your head will always be the guys coming through ... that sticks in your mind. I always think of the hearse going by and seeing these Union Jacks and thinking of the family. That just sits in your mind forever. What the families are going through. That is what I think of when the word repatriation is said.
It was also evident that among some members of the local community, a strong sense of duty was attached to attendance at gatherings:

Betty: We would stay even for the late ones.

Karen: Yes, I'd stay late.

Lydia: It didn't seem right going home, did it?

Betty: No, not until you'd done it.

Lydia: Otherwise it was like you only did it because you happened to be there, and you weren't doing it because you should.

The idea of respect, and the importance of showing respecteven for those considered to be "outsiders"-was underscored in the focus group with town council employees. It also arose organically in discussion between local retailers:

Lois: To start with it was just local [people attending] but they [outsiders] just didn't know what to do. I think they felt frustrated that they couldn't help in any way-so to come and pay respects like that ... I think it's-yeah-why shouldn't they be able to?

Lydia: I think they [outsiders] came to be part of the community ... I don't think they interfered with anything ... only the press at one point ... but apart from that, they just stood and then went really.

Betty: I think as a community, but where we stood at this end, we had the community. We had the locals, that just wanted to come up quietly and do their thing-right down to the little old man who stood there, took his cap off, stood there crying and did his salute as the coffin went by. That's the people that I feel need the recognition-not the people that have got to stand up and get on the telly at the other end.

These quotes typify a common openness to "outsiders" during the repatriation events, but also serve to illustrate ideational demarcations being drawn that are ostensibly geographical, but also behavioural. In contrasting the tearful elderly gentleman solemnly removing his cap with those wanting to "stand up and to get on the telly", as one retailer suggested, there are nuanced ways of "showing respect" for those attending these events, ways that could be perceived as being uncomfortably different for people close to these events as "insiders". The following interchange between sixth form college students further illustrates this point:

Josh: I remember my Mum telling me about this time when she had seen people turn up by the bus-load, people coming on the bus to see the repatriation, and people started putting out their little chairs to sit down and wait an hour early just so that they could sit opposite the families. People would sit opposite the families on their chairs so that they could see people crying and stuff-they wanted to be right near the action. It was a bit weird, I thought, that you'd turn up early just so you could see the main bit.

Lewis: They went for the wrong reasons.

All: Yeah [nods of agreement]. 
Amy: I think a lot of people come out of respect, but a lot of people came because they saw it on telly.

Claire: I think people beyond local-unless it was family, or veterans, wives-a lot of people from outside came for that, it was the media coverage and maybe they had an interest in history or something along those lines and said 'oh, we want to see what it is about', so for completely the wrong reasons.

Thus, the act of showing respect perhaps had its own local conventions that were socially sanctioned and categorized as appropriate. This is not, however, to suggest that "outsiders" were unwelcome, quite the opposite. Their presence at the repatriation events was described with some wonderment:

Betty: I was surprised that they would come from Scotland or London to pay their respects, because part of me thought they would do that at the funeral ... but no, they wanted to do both.

Philip: I think they wanted to do both, because they wanted to see Wootton Bassett, see how it functioned on those days.

Lydia: Or, there is such a delay isn't there ... I think they wanted to welcome them home and support the families, because then they went off and it could be months before their bodies were released. It is a huge wait then before you can show your respects. It was perhaps a way to show your immediate respects or to immediately grieve- to make it real.

In focus group discussions, for those facing the repatriation events week-on-week, it became evident that a range of emotional challenges arose during the period when the hearses passed through the town, with several respondents flagging up the fine line to be managed between showing respect and intruding on the grief of others. As one retailer commented:

Lydia: You wouldn't even go to the bank just before it [the cortege] came because you wouldn't want to intrude on their grief down there.

In her words, "down there" refers to the area close to the war memorial where family members of the bereaved were situated. Again, space is conceptualized here as a means of showing respect to the bereaved. It functions as a checkpoint for the imposition of self-restrictions to avoid physical intrusion, but it also functions relationally as an emotional breakpoint. As discomforting as experiencing the events could be for local people, grief was commonly expressed as a relative phenomenon, felt in gradations, as it were. Nevertheless, as we shall see, the regularity with which the bodies of repatriated service personnel passed through the town meant that grief was sometimes difficult to control and emotionally proximate. A member of the Royal British Legion focus group recounts one such occasion:

Jimmy: If you imagine standing there and all you can hear is these ladies sobbing and you see a Lieutenant Colonel standing there with tears coming down his eyes, with a Private standing beside him doing exactly the same thing. But they come up afterwards and say 'thank you very much for what you have done'.

What we have outlined above is a politics of respect that draws attention to space; who was considered to be an appropriate occupier of which spaces, alongside expressions of appropriate motivation. This politics ostensibly translated into what might be called "the rules of mourning" and the kind of conduct considered appropriate for these events.

\section{Managing the presence of death: mourning rules and appropriate conduct}

As the discussion above infers, attendance at gatherings did notin the eyes of the local people we spoke to at least-necessarily in itself constitute the paying of respect. Rather than being a takenfor-granted phenomena, a series of tacit protocols developed over time around how respect should and ought to be paid. Thus, while there were notable areas of contention, a range of actions and procedures became associated with the appropriate mourning. Within this, dignified and modest practices were valorized and demonstrative practices such as clapping and cheering were at first frowned upon as new conventions, due to the repatriation events initially conferring to tacit mourning rituals typified by silence. So showing of respect was not only connected to the "right reasons" as indicated above, there were also unwritten but strong behavioural expectations with regard to how to express this. Thus, a series of mourning rituals developed over the course of these gatherings that became both internalized and largely adhered to by local people. Echoing funeral customs, the maintenance of silence as soldiers' coffins passed through the town was deemed to be particularly important:

Amy: The first time I saw a repatriation, or whenever you saw it, you just stood there, it was an instant reaction. No-one told you to stand still and be quiet, it just happened.

Cathy: You see a hearse go past-there was a day, in my grandmother's days, when men would take their hat off and they would stand quietly by the road if a hearse went pastdon't matter who they were. And I think this is the old British way. I think this is what we did in Wootton Bassett. It is the traditional way of honouring those who have lost their lives.

Interestingly, we found no difference between older and younger people in their understanding of the importance of silence as an integral indicator of paying respect:

Amy: There would be times when I had to get the bus home, because I live [nearby] ... school buses going home are really noisy, but as soon as you knew a [hearse] car was coming down, everyone was quiet on the bus. But no one said anything, and that is a bus full of children. You wouldn't expect them to understand, but everyone just did it.

Claire: When we were walking home from school, everyone was quiet, just standing silently at the end of their road.

Karen: You could always tell when it was going to come through, even if it was late, because there was just that sense in the air. ... All of a sudden it would go quiet, and you'd think 'oh its on its way' and you would go to the front of the shop and sure enough people were moving towards the front of the road to stand.

Jimmy: When you are out there and see the youngsters. [Boy] was only 8 at the time, he was standing there, okay he was standing with his grandparents, and he was paying his respect as well. And you see other kids. Kids coming out of the senior school, chatting away, the bell would toll and they would stop and pay their respects. It's not just the older people ...

Clearly, silence was central to maintaining due solemnity and indicative of respect giving. In contrast, the intentional breaking 
of silence was seen as taboo and deemed to be inappropriate. Indeed, those who broke the rule of silence as the corteges passed through were likely to be met with short shrift, whether it be electronic intrusions such as mobile phones or the click of a late comers high heels:

Lydia: There's no mobile phones-I've never heard a mobile phone, just occasionally someone clonking along in some shoes, and then ...

Karen: ... everybody would glare, and they would freeze, like a rabbit in headlights! (laughs)

So, for many local participants that had attended the showing of respect was bound by unwritten rules of conduct. Respect that "counted" for them was shown for the "right reasons", in the correct way, with the maintenance of silence and grieving distance from the bereaved being seen as central.

It is important to note that adhering to mourning rules was seen to be important not simply for the arbitrary maintenance of order but also in terms of appropriately showing support for bereaved families. As one might expect, the families of the bereaved came up often in discussion and were frequently cited as a reason for attending gatherings:

Philip: They paid the ultimate price. They deserve to be recognised.

Betty: It's our little bit for that certain solider.

Karen: And our respect to that family. I think by us turning out, the family that were there-they can see how many people turned out-and I think that must help them. We've heard it said that the families said that the respect the Wootton Bassett showed help them to come to terms with their loss.

Indeed, there is evidence to suggest that the efforts of the people of Royal Wootton Bassett were received in the intended fashion with members of bereaved families praising the efforts of people in the town. As a father (cited in Etchingham, 2011) remarked on the loss of his son:

It's the worst day of your life and you feel like the loneliest person in the world. But when you come to Wootton Bassett you realise you're not. You've got all these people. From children to pensioners, from the British Legion to motorbikers. It gives you comfort in your heart.

It is important to remember that the repatriation events at Royal Wootton Bassett were a complex mixture of public and private grief arranged and conducted in the public domain. As the repatriation gatherings matured, a particular place of remembrance was offered adjacent to the war memorial in the town for bereaved families to stand. The funeral cortege stopped momentarily at this spot to allow family members to place flowers on the top of the hearses. On 4 July 2010 many newspapers published the poignant image of Helen Fisher performing this ritual. Carrying a small bunch of flowers, she is pictured walking out of the crowd towards the hearse carrying the body of her 20-year-old cousin, Private Douglas Halliday. The picture depicts an intensely private moment which is also a very public one, shared as it was, not only with those present at the gathering, but also millions of media consumers around the world. The people in our focus groups commented on this mixture of public and private expression of grief and the different ways in which it was expressed.
Interviewer: There are some traditional ways we think about grieving, for example as in silence ...

Betty: I didn't like the applause.

Karen: No, no.

Lydia: See, it didn't bother me, because you have to do what you have to do to get you through.

Betty: I think in the end, they were treating it like a funeral.

Lydia: They were saying 'well done' weren't they? I can sort of see where it came from.

Betty: It was the youngsters ... I think it was from the Diana era, the applause. Because they applauded her, didn't they? So I think that maybe that came from there, that the younger people-mainly the younger people do it.

Lydia: It was just a lot of young lads. Obviously his mates had come and you could see all their handprints (on the hearse) ... they just wanted to do something, I guess.

Betty: When you see the lipstick kisses-you can see all the lipstick kisses on the windows of the hearse and smear marks of someone's tear-stained fingers down the window.

These observations suggest not only ambivalence towards specific cultural practices, they also set fuzzy boundaries between more traditional modes of mourning (showing respect through silence) and less traditional modes of mourning that may intentionally break silence but as a display of public grief (just wanting to do something, clapping, kissing the hearses). Alongside this there is also a recognition that the gatherings were somehow different than a funeral and the mourning rituals that these presume. However regardless of inter-generational and regional practice-based differences, the importance of attending the repatriation events remained universal for local people of all ages:

Interviewer: Are there any differences between people who are older and people who are younger, do you think?

RBL (all): No.

David: All the youngsters, they all paid their respects.

David: During school time, the Head Girl and Head Boy would come down and join in.

Cathy: One of the ladies brought her children along because she felt that they should know what life was about. It was not something to be hidden but something to explain to themwhat they were there and what they were doing.

Lewis: Some [repatriations] we couldn't attend because we were at school, but we tried to go to as many as we could.

This sense of the paying of respect in public through appropriate mourning rules is connected here to supporting the families of the bereaved in their private grief and affords an interesting bridge into understanding the ways in which the presence of mortality was collectively managed in the town. 


\section{Repatriation and respect: tracing the presence of the ineffable?}

The contested terrain of differences between the old and young notwithstanding, there are some interesting glimpses in the data we have presented regarding the tensions between public and private grief and the public nature of repatriation, alongside the more private nature of the funeral. The recalling of "lipstick kisses" and "the smear marks of tear stained fingers" in the quote above are suggestive of the ineffable: that which cannot be uttered, that which only exposure to death can provoke. Clearly the repetitive presence of mortality on a scale, such as that witnessed by the people of Royal Wootton Bassett, can produce disquieting effects that have to be both individually and institutionally confronted and managed. Many of our research participants talked about the impact witnessing repatriations had had on them. These included managing their own emotions and that of witnessing the emotion of others. A town council worker talked about the feeling of anticipation she experienced when taking up post before her first repatriation:

Jenny: To be honest I was always waiting for it. I didn't know how I was going to react. I had never stood out there before, it was going to be a completely new thing to me. You would hear it on the radio, someone has been killed, and then I kind of started thinking it is all going to start happening now. The day of my first repatriation I was really, really nervous because I didn't know what to expect. And I didn't know how I was going to react to it ... I didn't want to stand there and be really emotional and fall to bits when it wasn't ... I am not a member of the family and I haven't been personally affected, so I didn't feel I had the right to feel like that. But also I didn't know how I was going to feel. It was-it is-it does affect you emotionally and you have to stand there and be professional about it and also take the phone calls and take the enquiries and also remain professional.

Jenny describes here the problems that arise for the self in having to navigate a course between professional standards of public display and innermost emotions in a highly charged environment. Aside from the respondent above, several other participants talked of the cumulative emotional toll that the gatherings took on them personally and the memory traces that would remain indelible:

Lydia: It was very hard to get on afterwards, wasn't it? It was quite hard to return to what you were doing, because you'd hear the families sometimes.

Betty: That day that woman followed the coffin down the high street. She ran down the high street, following her son.

Lydia: That was awful. We've all got kids, haven't we?

Betty: Still gets to you now.

Lydia: It brings it home. That was hard. It was hard once they'd gone through, it didn't seem right just to carry on really.

\section{And from the Royal British Legion group:}

Cathy: Although grief can be a private thing, when you are gathered together the way we were, grief becomes a little bit more open. And no one is afraid to show it.

Jimmy: I will admit, there were many times I would stand there, with tears in my eyes. Because in four and half years of doing it, you think by this time you'd be hardened, but when you stand there and you listen to the women and the kids crying their eyes out, and that it all you can hear, there is no other sound ...

Cathy: But it is not just the women. As you say, it can be a very private thing in some respects, but in the body we were down there, people weren't afraid or ashamed to show their grief. It was much more open.

Echoing the sentiments of a member of the Royal British Legion focus group, one of the retailers commented on the emotional challenges that the gatherings engendered and the ways in which $s($ he) attempted to manage them:

Betty: I got that I did so many that I ... when they actually finished, part of me was actually relived, because I got like I couldn't cope. My coping mechanism was not knowing who they were. I wouldn't read about it, I don't read a newspaper. I don't take that side of it in, because I don't want to know. My coping mechanism was not to know who they were. That might sound odd, but that is how I coped. Everybody coped in different ways.

So, expressions of mourning and exposure to death, added to silence and the politics of respect, offer a sense of how these repatriation events were socially shared, constructed and understood, and, moreover, what kind of meanings and impact they had for local people. However, what also surfaces here are some deeper issues reflecting contemporary understandings of death and its relationship with that which is ineffable.

As discussed earlier, the repatriation process is one aspect of what Kellaher and Worpole (2010) refer to as "bringing the dead back home". For 5 years, people living in the town of Royal Wootton Bassett experienced this process at very close quarters, regardless of their involvement in repatriation gatherings. In this context, "bringing the dead back home" meant sensing, seeing and dealing with the consequences of death with a frequency which is unusual in the modern age. This process, as documented here, may have some connections with the observation made by Kellaher and Worpole (2010: 174) that "the dead and bereaved are now, for many, released from the theological, ecclesiastic and municipal boundaries within which they have been retained and their meaning managed for centuries". The gatherings that took place at Royal Wootton Bassett-and the repatriation events at Carterton-are arguably constitutive of social spaces in which new ways of bringing the dead back home have been developed. Drawing on the work of Douglas, Maruna (2011: 4) perceptibly observes that there are certain things that cannot be experienced without ritual. While he goes on to develop this point in the context of the re-entry of offenders into society, it is tempting to walk further down the line with a cultural/symbolic approach.

What we have in the case of military repatriation is arguably the development of a ritual that marks the re-entry of a dead soldier in symbolic terms, not just into the arms of his/her family but also into the arms of the nation for which they were fighting. Furthermore, it is evident in the testimonies of some of our participants that they saw themselves in many ways as representing distant and absent mourners by proxy. One Royal British Legion participant, David, expressed it this way: "we didn't just represent ourselves, we represented all the countries, all the people that couldn't get here". In creating this rite de passage it is possible to discern not the sequestration of day-to-day life, in which the unspeakable become "squeezed into the side-lines" of 
everyday life (Giddens, 1991: 157) but, more importantly, the public embrace of the unspeakable. In this public embrace, there are tensions around how to engage in its practical accomplishment, as illustrated in some of the data presented here: clapping, silence, lipstick kisses and other public displays of emotion. However, despite the emotional drain and the episodic presence of death a functional unity was maintained in the town. This may have transpired because of the coming together of events, individuals and processes at a particular point in time. Some respondents suggested that this was a mixture of pure happenstance and the organic development of tacit rules and rituals. But it is possible to suggest that this public embrace of the unspeakable has much more to it than happenstance and the commitment of respectful mourners. Arguably in tracing the presence of the ineffable in these events, the unspeakable becomes multi-layered and multi-faceted. This alone is suggestive of the need for further reflection on the merits and limits of the sequestration thesis when applied to the contemporary context.

Stanley and Wise (2011: 950) argue that Giddens' sequestration thesis has "troublesome" aspects insofar as "people do not deal with dying in the same way, and different kinds of deaths are precisely different for the people dying as well as those close to them". This observation is endorsed in the data we have presented here. Different experiences produce different responses and generate different socio-cultural practices. In the case of Royal Wootton Bassett, we have arguably witnessed the construction of what Berlant (2011) describes as an "intimate public". In defining this she goes on to suggest:

In an intimate public one senses that matters of survival are at stake and that collective mediation through narration and audition might provide some routes out of the impasse and the struggle of the present, or at least some sense that there would be recognition were the participants in the room together. (Berlant, 2011: 226)

Reminding us that "public spheres are always affect worlds" (Ibid.), this sense of an intimate public is one that resonates strongly with the two themes that we have presented here around the politics of respect and managing the presence of death. Mutual recognition between all the "mourners" present at a repatriation event, and the behaviours and practices that such events generated not only afforded comfort for the grieving for lost sons and daughters but it also afforded comfort for those not so directly affected. The events themselves, so documented and experienced, constitute a route out of "the impasse and the struggle of the present" (Ibid.). In this public affect, and its associated emergent cultural rituals, the unspeakable, the affect of grieving, was given space and recognition. This is one layer of the ineffable the faint lines of which are traceable in these events. There is, however a second line, much more political in its tone, also implied in Berlant's (2011) construction of an "intimate public" captured in her use of the word "struggle".

Arguably, the unspeakable and unspoken struggle lying behind the repatriation events at Royal Wootton Bassett was the wars in Iraq and Afghanistan. This was the "elephant on the High Street" for all concerned. As Jenkings et al. (2012: 6) observe:

The emergence of the Wootton Bassett phenomenon may have been spontaneous, but it occurred at a time when the government and military were deliberately attempting to 'reconnect' the military with the public in the wake of the unpopular Iraq war.

While they go on to recognize contested meanings were attached to Royal Wootton Bassett as it was constructed and represented in the media, it is evident that these events and their meaning became difficult to control politically. This is evidenced in individuals with competing proclivities using social and broadcast media to challenge as well as to endorse military involvement in Afghanistan and Iraq (see Bagehot, 2011). Indeed, some have argued that the thorny questions about geo-political military strategy that Royal Wootton Bassett threw up very much underlay the rationale for the move to Carterton-as a popular Facebook campaign suggested in the Summer of 2011. In our focus groups, the lessened media coverage of repatriated soldiers since the move to Carterton was a frequent topic of discussion. The potential for the political as a feature of the unspeakable to be traceable in these events adds further weight to the wider public discomfort that they generated.

\section{Conclusion}

What we have presented here is an analysis of a nascent and dynamic public ritual: military repatriation. It should be noted that military repatriations are certainly not unique to Royal Wootton Bassett. Similar events have occurred in other countries, such as Canada, and, post "Bassett", in other places in the United Kingdom, albeit on a much smaller scale. Nevertheless, what Royal Wootton Bassett did was to bring to the public imaginary a way of mourning publicly in the context of politically contested wars. While we have commented in detail on the meanings associated with the gatherings at Royal Wootton Bassett for those that lived with and through them, our discussion raises questions that tap into broader sociological debates about the constitution of the public sphere in contemporary society and the diversity of political practices expressed therein (see Beck, 2012; Zizek, 2013).

While repatriations in and of themselves might be considered on the margins of social and cultural transformations associated with bereavement, rendering those practices speakable has important consequences. Those consequences lie within an understanding of the ineffable and our ability to trace its presence in the everyday world of human responses to difficult circumstances. Inasmuch as the sequestration thesis suggests that we have developed structures and practices that both distance us from and insulate us against dealing with human conditions of pain, suffering, madness and death, the shifting terrain on and in which mourning and grief are being publicly expressed are indicative of the need to delve further and deeper in this area. In affording the space for an "intimate public" to exist, Royal Wootton Bassett has indeed not only changed the way in which we "mark the sacrifice of war" but also encourages us as social scientists to critically reflect on the extent to which the theories that we have constructed enable us to make sense of contemporary practices of commemoration and memorialization. From the reading of the data presented here these practices are certainly not cynical or inauthentic.

\section{Notes}

1 We place "mourners" in inverted commas here to indicate that in this context this word is used to cover all of those people who witnessed first-hand gatherings in the town, regardless of their reasons for attending.

2 The town of Royal Wootton Bassett bore witness to the repatriation of 345 of these personnel during a total of 167 military repatriations that passed through the town.

3 The planes landed at RAF Lyneham rather than the preferred landing point of RAF Brize Norton, as repairs were being undertaken to the runway at the latter base.

4 Wootton Bassett was the first town to have been bestowed with such status in over 100 years.

5 The colleague who provided these images of Royal Wootton Bassett is professional photographer, Stuart Griffiths.

6 These were third-year university students of mixed ages and sex but predominantly white and English. 
7 These focus groups comprised those identified as consistently engaged in the repatriation process: retailers, council workers, students from the local Academy and members of the Royal British Legion.

\section{References}

Allen M (2015) The Labour of Memory: Memorial Culture and 7/7. Palgrave Macmillan: London.

Bagehot W (2011) The Economist, 8 September, http://www.economist.com/blogs/ bagehot/2011/09/britain-and-its-war-dead-0, accessed 3 June 2014.

Beck U (2012) Twenty Observations on a World in Turmoil. Polity: Cambridge.

Berlant L (2011) Cruel Optimism. Duke University Press: Durham, NC.

Bond K (2008) The inside story of Wootton Bassett's repatriations, Gazette \& Herald, http://www.gazetteandherald.co.uk/news/3998140.The_inside_story_ of_Wootton_Bassett_s_repatriations/, accessed 3 June 2014

Braun V and Clarke V (2006) Using thematic analysis in psychology. Qualitative Research in Psychology; 3 (2): 7-101.

Drake M (2011) The returns of war: Bodies, images and invented ritual in the war on terror. In: Karatzogianni A (ed) Violence and War in Culture and the Media. Routledge: Oxon, UK.

Drake M (2013a) Commemorating fatalities of war and national identity in the twentyfirst century. In: Ogden C A, Wakeman S (eds) Corporeality: The Body and Society. Issues in the Social Sciences: 8. University of Chester Press: Chester, UK.

Drake M (2013b) The war dead and the body politic: Rendering the dead soldier's body in the new global (dis)order. In: McSorley $\mathrm{K}$ (ed) War and the Body: Militarisation, Practice and Experience. Routledge: Oxon, UK.

Doss E (2008) The Emotional Life of Contemporary Public Memorials: Towards a Theory of Temporary Memorials. Amsterdam University Press: Amsterdam, the Netherlands.

Etchingham J (2011) Fallen Heroes. London: BBC News, http://fallenheroes.org.uk/ farewell-wootton-bassett/, accessed 3 June 2014.

Fassin D (2014) The discreet charm of police ethnography: Plenary address, British Criminology Conference, Liverpool.

Foley M and Lennon J (1996) JFK and dark tourism: A fascination with assassination. International Journal of Heritage Studies; 2 (4): 198-211.

Foley M and Lennon J (2010) Dark Tourism: The Attraction of Death and Disaster. Cengage Learning: Hampshire, UK.

Giddens A (1991) Modernity and Self-Identity. Polity: Cambridge.

Jenkings K N, Megoran N, Woodward R and Bos D (2012) Wootton Bassett and the political spaces of remembrance and mourning. Area; 44 (3): 356-363.

Kellaher L and Worpole K (2010) Bringing the dead back home: Urban spaces as sites for new patterns of mourning and memorialisation. In: Madrell A, Sidaway J (eds) Deathscapes: Spaces for Death, Dying and Bereavement. Ashgate: Abingdon, UK.

Martinsen K D (2013) Soldier Repatriation: Popular and Political Responses. Ashgate: London.
Maruna S (2011) Re-entry as a rite of passage. Punishment and Society; 13 (1): $3-28$.

McGarry R (forthcoming) Conducting "community orientated" military research. In: Williams A J, Woodward R, Jenkings K N, Rech M (eds) Ashgate Research Companion to Military Research Methods. Ashgate.

McGarry R, Mythen G and Walklate S (2012) The soldier, human rights and the military covenant: A permissible state of exception? International Journal of Human Rights, Special Edition on the Sociology of Human Rights; 16 (8): 1183-1195.

McGarry R, Mythen G and Walklate S (2013) Exploring "Bassett": The Politics of Respect, Silence and Mourning. Inter University Seminar Series on Armed Forces and Society, Chicago, IL.

Natcen. (2012) British social attitude survey 29, http://www.natcen.ac.uk, accessed 7 August 2014

Stanley L and Wise S (2011) The domestication of death: The sequestration thesis and domestic figuration. Sociology; 45 (6): 947-962.

Thomas P (2010) Doing case study: Abduction not induction, phronesis not theory. Qualitative Inquiry; 16 (7): 575-582.

Walklate S, Mythen G and McGarry R (2011) Witnessing Wootton Bassett: A silent protest? Crime, Media, Culture: An International Journal; 7 (2): 1-17.

Woodward K (2009) Statistical Panic: Cultural Politics and the Poetics of Emotion. Duke University Press: Durham, NC.

Valier C (2004) Crime and Punishment in Contemporary Culture. Routledge: London.

Winter J (1998) Sites of Memory, Sites of Mourning: The Great War in European Cultural History. Cambridge University Press: Cambridge.

Zizek S (2013) Demanding the Impossible. Polity Press: Cambridge.

\section{Additional Information}

Competing interests: The authors declares no competing financial interests.

Reprints and permission information is available at http://www.palgrave-journals.com/ pal/authors/rights_and_permissions.html

How to cite this article: Sandra W, Gabe M and Ross M (2015) "When you see the lipstick kisses ..." - military repatriation, public mourning and the politics of respect. Palgrave Communications 1:15009 doi: 10.1057/palcomms.2015.9.

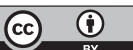

This work is licensed under a Creative Commons Attribution 3.0 International License. The images or other third party material in this article are included in the article's Creative Commons license, unless indicated otherwise in the credit line; if the material is not included under the Creative Commons license users will need to obtain permission from the license holder to reproduce the material To view a copy of this license, visit http://creativecommons.org/licenses/by/3.0/ 